\title{
学術調㚗班報告
}

\section{X線テレビの映像系の維持管理に関する調查の報告 ならびに保守管理実施の項目と方法}

\author{
平成6年度学術委員会X線TVの維持管理に関する検討調查班 \\ 班長 村西久幸 神奈川県立厚木病院 放射線科 \\ 班虽 細矢志郎 国家公務員等共済組合運合会虎の門病院放射線部

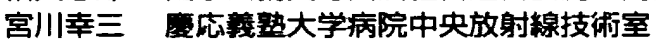 \\ 斎藤裕久＼cjkstart国立がんセンター東病院放射線部 \\ 小憣諘治 株式会社東芝那須電子管工場イメージ管技術部
}

\section{1.はじめに}

X線TVの放射線診断上の役割は，CR時代の今日で も必要不叮久である。むしろX線TVの機能は一層充䒠 されるこ上が期待されていると考える。今机イメージ インテンシファイア(以下I.I.上する)の関倸を含め, X 線TV (映像采)の維持管理につつて奉態調杳を㧍こな った。またこの調查の結果をも之に，月常機器使用者

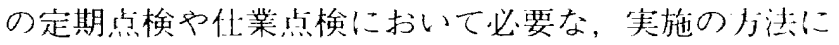
ついて娭討する。

使用者のI.I.X線TV(映像系)の維持管理に関卞るア ンケートか斻る上，保守管理について多くの意見 がある。そ机らを問題群に分けて十なものを次に列举 寸る。

○定期的な保守管理を必要とし，データをチェッ クする事により父換に必要な情報を得たい。

变換倸数GX值等で，具体的な交換時期を規宝しし 数值等で表示させたい。

○計測器具や簡単な維持管理の方法を唡討し, 备 メーカーで統一した方法を作り使用者が簡便に 実施できるようにしたい。

○性能及び経年变化による性能少化データをメー カーより提供してほしい.

○TV系など故障を米然に防ぐため定期点娭を行 い，画像少化，ノイズ発生など調整修理を必要 とする。

高精細化が進志中，准故障が以前より多発し ている。解像力们上のため超高品位モ二夕や新 しい画像処理システムの開発改良を望む。

○学会等で画像抢よび線量の規定を作ってはし い.

○劣化による被曝線量の増加は無視できない。

高額なため定期的な交換や保守点娭は難しい。

○画像が完全に映らな くならないと修理交 換にならない。

シ京用は，定期的に 保守点娭书上び交換 を行うが，消化管用 では画像の少化だけ では交換が認めら机 ない. 故障や, 光学
柔の少化があっても予算面で交換ができない。

CI.1.系TV系のみを父換しても新品時の性能は得 られず，装置目体在変える力がよい。

○設置時の技術者の筑があり，より熟練したサー ビスを望む。

ト記のアンケートからの意見にも見ら机るように， I.I.やTV系の保守管理について高い関心が見られる。 特に，維持管理や劣化の調查に関する意見が多く，そ のち法や規超が望ま机ている。しかし一万では，画像 が穵全に劣化をしなけ机ば，父換しなかったり，また できない事情があるようで，現状では定期点娭や，少 化の测定調整に無関心で比較的問題がないとか, 認識 が不足であったとの意見もある。こ狄らの意見の多く は，少化による被曝線量の増加の防止も含めて現状の 保持管理の力法の見淔しを望んでおり，映像采を中心 に11常管理を娭部する必要がある。

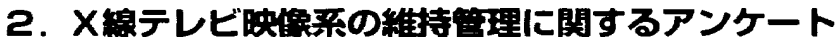 調章の啹告}

\section{$2-1$ 調査の概要}

調查のお願いは，独自に作成したアンケート用紙と 内容で下記の期間上対象に行った。

調查の期間：壮成 6 年 7 月 1 日一 7 月20日まで 調查の対象：全国の大学，総合，一般，がん専門等の 昞院，娭診機関の中から無作為抽出

対象個数：339施設に発送した

回答個数：188施設から回答があった回答率 $55.5 \%$ 2-2 調査の結果と内容

1) 回答施設の分類 (Table 1)

2）質問 $1, T V \cdot 1.1$. の使用範囲 施設別保有数 装置台数之I.I.の本数 (Table 2)

Table 1 回答施設の分類

\begin{tabular}{lcc|cc|c|c}
\hline & 大学病院 & 総合病院 & 一般病院 & がん専門 & 検診機関 & その他 \\
\hline 回答数 & 54 & 52 & 28 & 12 & 37 & 5 \\
回答率\% & 28.7 & 27.7 & 14.9 & 6.4 & 19.7 & 2.7 \\
外来患者数平均 & 1618 & 1155 & 406 & 578 & - & 130 \\
病床数平均 & 906 & 508 & 176 & 370 & 43 & 208 \\
TV使用患者数平均 & 40.8 & 29.1 & 16.8 & 27.2 & 49.2 & 8.4 \\
TV保有台数平均 & 13.2 & 8.1 & 3.8 & 8.6 & 7.8 & 3.4 \\
\hline
\end{tabular}


Table 2 TV・1.1.の使用範囲 施設別保有数 装置台数と1.I.の本数

\begin{tabular}{|c|c|c|c|c|c|c|c|c|c|c|}
\hline \multirow{2}{*}{ 用 途 } & \multirow{2}{*}{ 保有施設数 } & \multirow{2}{*}{ 装置総数 } & \multirow{2}{*}{ 装置平均 } & \multicolumn{7}{|c|}{ I.I.サイズと本数 } \\
\hline & & & & $\sim 14$ & $13 \sim 12$ & $11 \sim 9$ & $8 \sim 7$ & $6 \sim$ & 12 6可変 & 11総数 \\
\hline 1）血管造影裝置 & 127 & 323 & 2.5 & 44 & 28 & 123 & 10 & 6 & 159 & 370 \\
\hline 2) 消化管用等X-TV & 174 & 552 & 3.2 & 9 & 37 & 396 & 8 & 7 & 92 & 549 \\
\hline 3）間接撮影装置 & 32 & 60 & 1.9 & 1 & 14 & 2 & 0 & 0 & 40 & 57 \\
\hline 4) 泌尿器用X-TV & 87 & 111 & 1.3 & 5 & 18 & 72 & 4 & 3 & 11 & 113 \\
\hline 5）外科用（手術室） & 126 & 216 & 1.7 & 0 & 5 & 70 & 33 & 92 & 15 & 215 \\
\hline 6）治療用（位置決め等） & 87 & 116 & 1.3 & 6 & 29 & 53 & 5 & 4 & 9 & 106 \\
\hline 7）検診車撮影装置 & 52 & 205 & 3.9 & 0 & 51 & 5 & 0 & 0 & 145 & 201 \\
\hline 8）その他 & 32 & 41 & 1.3 & 5 & 4 & 16 & 2 & 10 & 6 & 43 \\
\hline 総数 & & 1624 & & 70 & 186 & 737 & 62 & 122 & 477 & 1654 \\
\hline$\%$ & & & & 4.2 & 11.2 & 44.6 & 3.7 & 7.4 & 28.8 & \\
\hline
\end{tabular}

解説 ○血管造影装置では12 と同インチ可変管が50.6 \%，9インチ管が33\%である。

○消化管用では9インチが72\%，12と同インチ稼 働管が23.5\%である。

○泌尿器用では9 インチが $63.7 \%$ である。外科 用は7〜6インチが58\%である。

間接，検殓車では12 と同インチ可変管が97.5 \%を占める。

○14インチ管は血管装置に総数の63\%使用され ている.
質問 $2 ， 1 ）$ 装置のDSA. DR. 用の台数と比率は？ 104施設回答 合計 260 台／装置総数1624台 比率 $16.0 \%$

2) 高精細X-TV (1000本以上)の台数と比率は? 98施設回答 合計 291 台／装置総数1624台 比率 $17.9 \%$

DSA. DRの保有台数 (Table 3)

OTV装置のDSA. DR.は64\%が大学病院，33\% が総合がん専門病院にある。

質問3，I.I.のこれまでの保守点検についての質問

1) 購入時装置の引き取り 検查を行ったか

引き取り娭査の実施状 況 (Table 4)

○装置の引き取り検 査については検診 施設が $91.9 \%$ と高 い。これは集団娭 診における精度管 理の普及率が高い ことが考えられ る.

○一般病院では36 $\%$, 総合病院でも $53.8 \%$ と低い実施で ある。

2）保守点蚞を行ったこと があるか

保守点娭実施状況 (Table 5)

○保守点娭について は，大学病院，枱 診機関が高い実施 率であるが，一般 病院でも，63\%以 上実施である。

3)保守点検契約が有るか 
無しか

契約点検実施状況 (Table 6)

保守点検を契䄪をして実施し ている施設は，娭診機関が70 \%と多いが, 大学病院等では $30 \%$ と低い.

○保守点娭の契的回数について は回答数92施設で，年平均 2.5 回である。

4)これまでの保守点娭の方法 自 主点検の可能な範囲を問う

保守点娭の方法 (Table 7)

○解像度については比較的子ャ 一トによる観察が容易である ため63\%が用いている。

G $\mathrm{Gx}$ ひずみ，面品位，につい ては，I.I.出力面の直接観察之 なるため測定器使用は少ない。

質問4，I.I.のこ机から必要と考えている保守点唡につ いての質問

1) 購入時引き取り検査の必要の有無 (Table 8)

○引き取り検査については検診機関が100\%, 大学が96\%必要としており，この方法につい て，簡易的に加つ数年の恒久的経過観察の可 能な方法の開発が必要となる。

2) 保守点娭の必要の有無 (Table 9)

○保守点唡については各施設とも高い必要性を 認めている。

保守点検の必要な回数については平均 2 回/年 である。

○保守点娭の必要な回数は，DSA，などを含も 血管造影装置と，一般のX-TV装置では，異 なると考えられる。(Table 10)

3)これからの保守点検の方法(Table 11)
Table 7

\begin{tabular}{l|c|c|c}
\hline \hline a) 輠度 (Gx)の測定 & 1. 測定器による & 2. 透視条件の比較による & 3. 不可能 \\
\hline 回答173 & $49(28.3 \%)$ & $87(50.3 \%)$ & $37(21.4 \%)$ \\
\hline
\end{tabular}

\begin{tabular}{|c|c|c|}
\hline b) 解像度 (MTF) の測定 & 1.チャート撮影による & 2. 目視による \\
\hline 回答172 & $109(63.4 \%)$ & $63(36.6 \%)$ \\
\hline
\end{tabular}

c）ひずみ度の測定 1.メッシュチャートによる 2 2. 目視による

\begin{tabular}{l|l|l|l} 
回答170 & $82(48.2 \%)$ & $88(51.8 \%)$ & $\begin{array}{c}\text { 2, 両方は } \\
\text { 1へ算入 }\end{array}$ \\
\hline
\end{tabular}

\begin{tabular}{l|c|c} 
d) 面品位(白黒点など) & 1.コリメータによる観察 & 2. 目視による \\
\hline 回答166 & $19(11.4 \%)$ & $147(88.6 \%) \quad \begin{array}{c}\text { (1. 2, 両方は } \\
\text { 1へ算入) }\end{array}$
\end{tabular}

○保守点㮩に際して多くの施設が測定器による 監視を望んでいる。 質問5，I.I.の故障修理についての質問

1）通常I.I.は，故障しますか(Table 12)

○I.I.の故障については，検診車の移動の関係 か，唡診機関に多い。

○一般病院，がん専門病院では比較的少ない.

○通常の故障については $28 \%$ と予想外に多いの ではないか.

2) a）故障の頻度は, 稯数での平均值

回答90施設で，8.8年で，8.7本中 2.87 本の故 障頻度となる。

10 年で 5 本中 1.65 本の平均となる。

b）単品では，回答27施設で1.37度/年 回答72施設で 1 度/5.46年

○設問が不明な所もあり分析が困難であるが, 5－6年に1度の故障と推察される。

Table 8

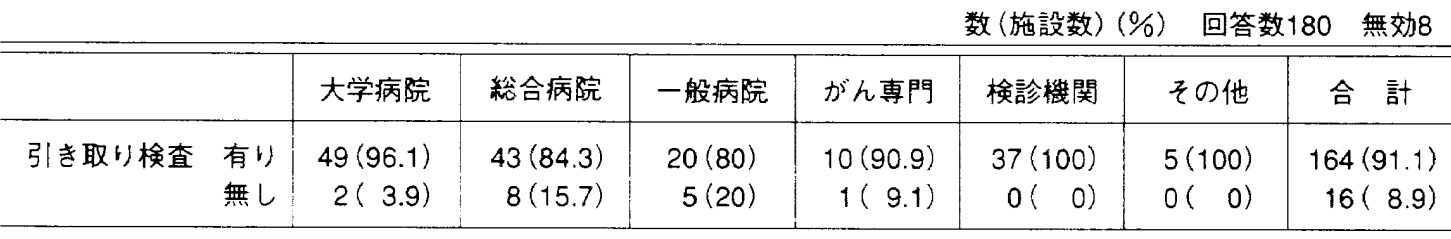

Table 9

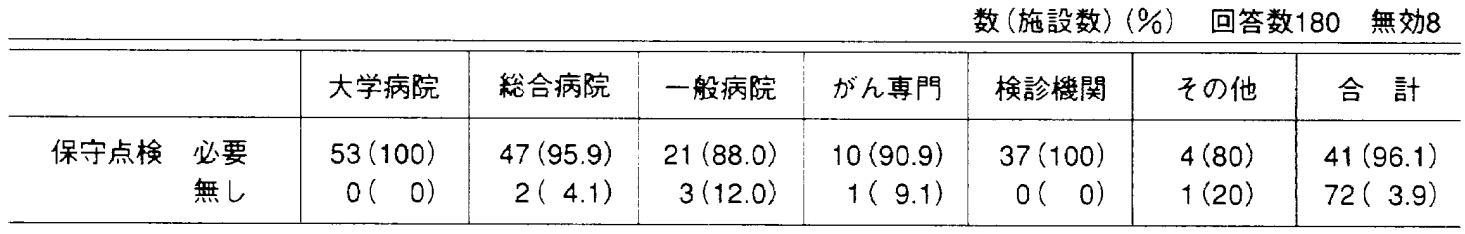

Table 10

\begin{tabular}{l|c|c|c|c|c|c|c}
\hline \hline 回数 $/$ 年 & 1 回 & 2 回 & 3 回 & 4 回 & 5 回 & 6 回以上 & 平均回数 \\
\hline 回答157 & $65(41.4)$ & $60(38.2)$ & $12(7.6)$ & $16(10.2)$ & $1(0.6)$ & $3(1.9)$ & 2 \\
\hline
\end{tabular}

1996 年 7 月 
Table 11

\begin{tabular}{|c|c|c|c|c|c|}
\hline a) 輝度 (Gx) の測定 & 1. 測定器による & \multicolumn{2}{|c|}{ 2. 透視条件の比較による } & 3. 不可能 & \\
\hline 回答177 & $154(87.0 \%)$ & \multicolumn{2}{|c|}{$22(12.4 \%)$} & $1(0.6 \%)$ & \\
\hline b) 解像度 (MTF) の測定 & \multicolumn{2}{|c|}{ 1.チャート撮影による } & 2.目視による & 3.その他 & \multirow[b]{2}{*}{$\begin{array}{l}(1 ， 2, \text { 両方は } \\
\text { 1へ算入 }\end{array}$} \\
\hline 回答177 & \multicolumn{2}{|c|}{$163(92.1 \%)$} & $13(7.3 \%)$ & $1(0.6 \%)$ & \\
\hline c）ひずみ度の測定 & \multicolumn{2}{|c|}{ 1.メッシュチャートによる } & 2.目視による & 3.その他 & \multirow[b]{2}{*}{$\begin{array}{l}(1 ， 2 \text {, 両方は } \\
\text { 1へ算入 })\end{array}$} \\
\hline 回答175 & \multicolumn{2}{|c|}{$155(88.6 \%)$} & $20(11.4 \%)$ & 0 & \\
\hline \multicolumn{5}{|c|}{ 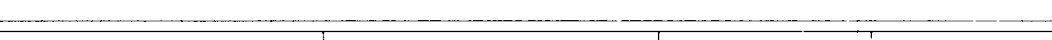 } & \\
\hline d）面品位（白黒点など) & \multicolumn{2}{|c|}{ 1. コリメータによる観察 } & 2. 目視による & 3.その他 & \multirow[b]{2}{*}{$\begin{array}{l}(1,2 \text {, 両方は } \\
1 \text { 人算入 })\end{array}$} \\
\hline 回答 170 & \multicolumn{2}{|c|}{$124(72.9 \%)$} & $46(27.1 \%)$ & 0 & \\
\hline
\end{tabular}

○定期的な交換は， 5-6年が多い。

2)-2 今は定期的な交換 をしないがするとし た場合の理想年数は

(Table 16)

$\bigcirc$ 今後の交換の理想年: 数は，一般的には 5 华と見なさ机るが， In管造影などのI.I.に ついは 3 年と推測 される。

3）施設のI.I.交換の規定は 有ります加(Table 17)

交換規定有りの施設 は14力所と少ない。 内4 3\%が検診機関で
この分析から平均的交換期間年数の参考になれ ばよい。

3) I.I.の故障の種類 (Table 13)

○解像度低下の中には，電源不良などによる焦 点不良, 輝度劣化によるコントラストの低下 によるものが含ま机ていると考えら机る。

質問6, I.I.の交換について

1) 定期的に交換します加(Table 14)

○I.I.の定期交換を古施設は，18施設 $9.8 \%$ と 僅かであり，そのうち娭診機関が $67 \%$ 占め る。これは胃集河検骖における精度管理上の 措置として定期的交換が必要である事の誑識 が普及してきた結果がよく示さ机ている上考 えられる。

2)-1 定期的な期間については(Table 15)
ある。

4)不定期に交換した理由としては(Table 18)

○不定期な交換理由には，画像劣化が多いが, 劣化の程度(使用限度)を設定することが困難 な場合がある。

○使用限度の設定には劣化の程度の定期的測定 が必要とさ扎るが，既に定期的測定結果から 交換さ扎ている施設が13施設あり，之の恒常 的測定注や，規定值に興味がある。

○交換の劣化の程度の安として, 工業会で は，初期の輝度の1/2を推奖している。この $\mathrm{Gx}$ ，または相対輝度の測定を普及する必要が ある。

○交換理由の結果加見て，画像少化のため交 換，とするものが，故障による交換理由の2

Table 12

数 (施設数) $(\%)$ 回答数 185 無効 3

\begin{tabular}{c|c|r|r|r|r|r|r}
\hline \hline & 大学病院 & 総合病院 & 一般病院 & がん専門 & 検診機関 & その他 & 合 計 \\
\hline 通常故障する & $19(35.2)$ & $11(21.2)$ & $4(14.3)$ & $2(16.7)$ & $15(42.9)$ & $1(25)$ & $52(28.1)$ \\
しない & $35(64.8)$ & $41(78.8)$ & $24(85.7)$ & $10(83.3)$ & $20(57.1)$ & $3(75)$ & $133(71.9)$ \\
\hline
\end{tabular}

Table 13

回答数 114 故障物件 194

\begin{tabular}{cc|cc|c|cc}
\hline \hline 故障の種類 & 1. 破損 (真空抜け) & 2. フラッシュ.ストレ- & 3. 解像度低下 & 4. 電源不良 & 5. 面品位 & 6. 楎度低下 \\
\hline 故障の件数 & 21 & 15 & 91 & 32 & 33 & 2 \\
$\%$ & 10.8 & 7.7 & 46.9 & 16.5 & 17 & 1 \\
\hline
\end{tabular}

Table 14

数 (施設数) $(\%)$ 回答数 183 無効 5

\begin{tabular}{r|r|rr|r|r|r|r}
\hline & 大学病院 & 総合病院 & 一般病院 & がん尃門 & 検診機関 & その他 & 合 計 \\
\hline 定期的交換する & $2(3.8)$ & $1(2.0)$ & $2(7.4)$ & $1(9.0)$ & $12(32.4)$ & $0(0)$ & $18(9.8)$ \\
しない & $50(96.2)$ & $50(98.0)$ & $24(92.6)$ & $10(91.0)$ & $25(67.6)$ & $5(100)$ & $165(90.2)$ \\
\hline
\end{tabular}


Table 15

\begin{tabular}{lcccc} 
& & 回答13 \\
\hline 期間 & 3年に1度 & 4 年に1度 & 5 年に1度 & 6 年に1度 \\
\hline 施設数 & 1 & 1 & 9 & 2 \\
\hline
\end{tabular}

Table 16

\begin{tabular}{cl|cl|l|l|l|l|l}
\hline \hline 期間 & 1 年 & 2 年 & 3 年 & 4 年 & 5 年 & 6 年 & 7 年 & 10 年 \\
\hline 施設数 & 1 & 8 & 17 & 4 & 30 & 3 & 1 & 1 \\
$\%$ & 1.5 & 12.3 & 26.2 & 6.2 & 46.2 & 4.6 & 1.5 & 1.5 \\
\hline
\end{tabular}

Table 17

数 (施設数) $(\%)$ 回答数 183 無効 5

\begin{tabular}{|c|c|c|c|c|c|c|c|c|}
\hline & & 大学病院 & 総合病院 & 一般病院 & がん専門 & 検診機関 & その他 & 合 計 \\
\hline \multirow[t]{3}{*}{ 交換規定 } & 有り & $4(7.7)$ & $3(5.9)$ & $1: 3.8)$ & $0(0.0)$ & $6(16.2)$ & $0(0)$ & $14(7.7)$ \\
\hline & 無し & $29(55.8)$ & $36(70.6)$ & $19: 73.1)$ & $7(63.6)$ & $24(64.9)$ & $4(100)$ & $119(65.7)$ \\
\hline & 作りたい & $19(36.5)$ & $12(23.5)$ & $6(23.1)$ & $4(36.4)$ & $7(18.9)$ & $0(0)$ & $48(26.6)$ \\
\hline
\end{tabular}

倍あることは，故障ゆえやむなく交換す

Table 18

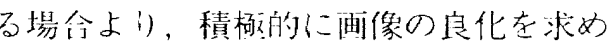

推進寺る良い傾问在示している。

5)迵去汇不最による交換の期間年数は(Table

19)

○1年以内の初期故障と抬もわ礼るものが 鼠も多い，年数计均は 5 年となる。

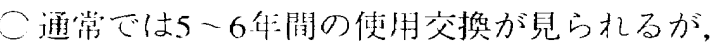
8-10年のものは装置の更新に伴うと推察で きる。

䁈胵7，X-TVカメラとモニターの保守管理について

1) 保讨点梌在しますか(Table 20)

○TVカメラやモニターの保守点蚞についても

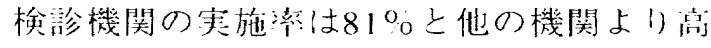

い。道に一般狱院では，50\%に立なない。

2) 保等占検の機会はいつですか(Table 21)
回答168 施設180件

\begin{tabular}{|c|c|c|c|}
\hline & & & 回答168 施設180件 \\
\hline 理 由 & 1、測定器による & 2. 画像劣化による & 3. 定期的な測定結果による \\
\hline 件数 & 55 & 112 & 13 \\
\hline$\%$ & 30.6 & 62.2 & 7.2 \\
\hline
\end{tabular}

○保守点検の機会は，定期点蚞が多く，中でも 検診棧関の75\%に達する。

3) TVカメラは故障しますか(Table 22)

a)故障の頻度は，1，2.84台/8.1台 2,2.3/年

$$
3,1 \text { 度/4.6年 }
$$

○故障の頻度は平均8台中 3 古に起こる，と56 施設が问答している。

故障の頻度は平均年に2 -3回起こる，と30施 設が间管している。

Table 19

\begin{tabular}{cccccccc:ccccc} 
& & & & & \multicolumn{1}{c}{ 回答129 } & 施設 138 件 \\
\hline 年 & 数 & 1 年以内 & 2 年 & 3 年 & 4 年 & 5 年 & 6 年 & 7 年 & 8 年 & 9 年 & 10 年 \\
\hline 件 数 & 23 & 8 & 17 & 11 & 22 & 21 & 0 & 18 & 1 & 18 \\
$\%$ & 16.7 & 5.8 & 12.3 & 8 & 15.9 & 15.2 & & 13.0 & 0.8 & 13.0 \\
\hline
\end{tabular}

Table 20

数 (施設数) $(\%)$ 回答数 183 無効 5

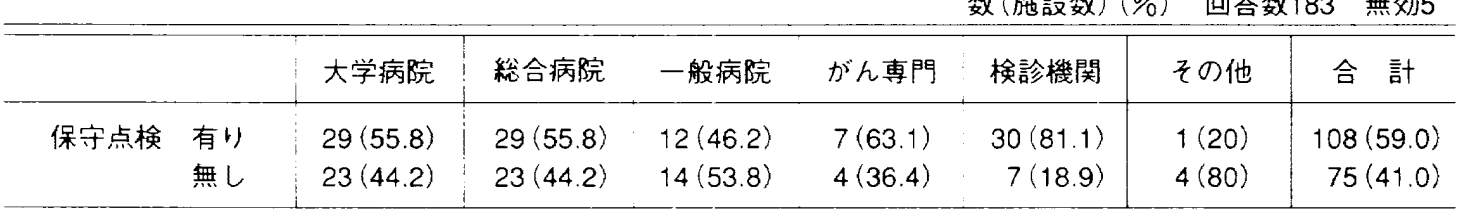

Table 21

\begin{tabular}{|c|c|c|c|c|c|c|c|}
\hline & & & & & (施設数) & 回答数 & 1 無効17 \\
\hline & 大学病院 & 総合病院 & 一般病院 & がん専門 & 検診機関 & その他 & 合 計 \\
\hline 故障の都度 & $24(48.0)$ & $25(50.0)$ & $8(40.0)$ & $5(45.5)$ & $8(22.2)$ & $3(75)$ & $73(42.7)$ \\
\hline 定期点検 & $18(36.0)$ & $20(40.0)$ & $11(55.0)$ & $5(45.5)$ & $27(75.0)$ & $0(0)$ & $81(47.4)$ \\
\hline 始業点検 & $6(12.0)$ & $4(8.0)$ & $0(0)$ & $1(9.1)$ & $1(2.8)$ & $1(25)$ & $13(7.6)$ \\
\hline その他 & $2(4.0)$ & $1(2.0)$ & $1(5.0)$ & 0 & 0 & 0 & $4(2.3)$ \\
\hline
\end{tabular}


Table 22

\begin{tabular}{l|c|c}
\hline & \multicolumn{2}{|c}{ 回答176 } \\
\hline 故障する & 件 数 & $\%$ \\
故障しない & 75 & 42.4 \\
\hline
\end{tabular}

Table 23

\begin{tabular}{l|c|c}
\hline \hline & 件 数 & $\%$ \\
\hline 撮像管(またはCCD) & 41 & 44 \\
電気回路 & 52 & 56 \\
\hline
\end{tabular}

Table 24

\begin{tabular}{c|c|c}
\multicolumn{2}{|c|}{} & 回答172件 \\
\hline & 件 数 & $\%$ \\
\hline 故障する & 108 & 62.8 \\
故障しない & 64 & 37.2 \\
\hline
\end{tabular}

Table 25

\begin{tabular}{l|c|c} 
& & 回答171件 \\
\hline \hline & 件 数 & $\%$ \\
\hline CRTの劣化 & 59 & 34.5 \\
電気回路 & 78 & 45.6 \\
画像の歪み & 30 & 17.5 \\
その他 & 4 & 2.3 \\
\hline
\end{tabular}

Table 26

\begin{tabular}{l|c|c}
\multicolumn{2}{c}{} & 回答91件 \\
\hline \hline & 件 数 & $\%$ \\
\hline 光学系 & 37 & 40.7 \\
スポットカメラ & 17 & 18.7 \\
オートアイリス & 22 & 24.2 \\
その他 & 15 & 16.5 \\
\hline
\end{tabular}

Table 27

\begin{tabular}{c|l|ll|l|l|l|l|l}
\hline \hline 年 数 & 1 年 & 2 年 & 3 年 & 4 年 & 5 年 & 6 年 & 7 年 & 10 年 \\
\hline $\begin{array}{c}\text { 件 数 } \\
\%\end{array}$ & 3 & 10 & 14 & 6 & 27 & 3 & 2 & 2 \\
\hline & 14.9 & 20.9 & 9.0 & 40.3 & 4.5 & 3.0 & 3.0 \\
\hline
\end{tabular}

Table 28

\begin{tabular}{c|c|c|c}
\multicolumn{2}{l|}{} & 回答164施設185件 \\
\hline \hline 理 由 & 1. 故障による & 2. 画像劣化による & $\begin{array}{l}\text { 3. 定期的な } \\
\text { 測定結果による }\end{array}$ \\
\hline 件 数 & 88 & 86 & 11 \\
$\%$ & 47.6 & 46.5 & 5.9 \\
\hline
\end{tabular}

故障の頻度は平均4.5年に一度起こる。と56施 設が回答している。

○この結果は故障の経験により差があり画一的 な判断はできない。

b) 故障の種類は (Table 23)

4) TVモニタは故障しますか(Table 24)

a) 故障の頻度は，1，4.15台/11.5台 2,2.5/年 3,1 度 $/ 4.0$ 年

○故障の頻度は平均11台中 4 台に起こる，上74 施設が回答している。

故障の頻度は平均年に2 3回起こる，と37施 設が回答している。

故障の頻度は平均 4 年に一度起こる, と73施 設が回答している。

○この結果は故障の経騃により差があり画一的 な判断はできない。

故障はカメラよりモニタの方が多いようであ る。

b) モニタの故障の種類は(Table 25)

モニ夕の故障は電気回路や，CRTの少化によ るものが多い.

5)その他の故障は(Table 26)

○その他TV系の故障として光学系などが挙げ られるが，使用装置の違いによって故障の種 類も異なる。

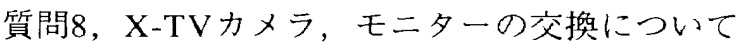

1) 定期的に交換しますか 定期系に交換する $11(6 \%)$
しない
$171(94 \%)$ 回答 182

2 ) 定期的な期間は(する場合) 3 年 1 件，5年 7 件，6年 3 件

2-2) 定期的な交換の理想とする年数は(Table 27)

3 ) 定期的に交換の規定(施設の)はありますか 交換の規定あり 6(3.4\%) 無し $133(75.1 \%)$
作りたい
$37(20.9 \%)$
回答 177

4) 不定期な交換理由は (Table 28)

OTV系の交換については，I.I.の劣化の問題と 平行して考慮に入れたいが，結果から見ても 交換の意識は少ない.

TV系の画像不良は，経年変化による劣化が 原因の場合があり，TV系の画像信号レベル や，撮像管の交換，について定期的な点娭を 受けるべきである。

モニターも1.1.同様に電源投入使用時間が長 く,コントラストや輝度については, 劣化の 程度は激しく点娭交換を考慮勧めら机る場合 がある。

5) 過去に不良による交換の期間年数は（Table 29）

○TV系においても通常では5－6年の使用交換 があるが，年数平均では5.3年となる。

質問9，映像系保守点唡用テストパターンについて

(Table 30) 
OTV内蔵(ROM)のSMPTEパ ターンについては, 現在 CT, MRI, DSA, などCPU 内蔵の装置においてソフト を搭載している事が多く， 普及しつつある。SMPTEで はTVモニター采や、マルチ カメラ, レザープリンター, の総合的な画像 管理に使用さ机ており，今㣪の，DR．装置 や，X-TV装置への搭載普及が望まれている。 I.I.用，TV用のテストチャートについては， 既に約 $50 \%$ の施設で使用しているが特に検診 機関の精度管理では仕業点検用として普及を 勧めている。

質問10, I.I.とX-TV采の劣化による透視, 撮影条件に วい下

1)あきらかに劣化による条件不足を感じた事があ るか

条件不足有り $142(78.0 \%)$

無ᄂ $40(22.0 \%)$ 回答 182

○I.I.やTV系の劣化による透視条件不足は，自 動調整が働いている場合徐々の変化には気づ かない場合が有り，最大值に近づいて初めて 暗くなっていることに気づくことがしばしば 有る。これらは，自動を解除して定期的な点 検が必要であり，思わぬ被曝線量の増加につ ながる。

2)アイリスの調整を行ったことがあるか

調整 有门 $129(7.13 \%)$

$$
\text { 無し } 52(28.7 \%) \text { 回答 } 128
$$

a)アイリスの内容

線量不足のためアイリスを開いた $91(63.6 \%)$ 画質向上のためアイリスを閉じた $52(36.4 \%)$ 回答 128 施設143件

○透視条件や，撮影条件を一定に保ち，劣化の 画像の改善を行う場合はアイリスの調整によ るが，I.I.間接撮影の場合は，画質の精状性に 留意が必要となる。

3) 自動輝度調整(透視条件増)の再調整をしたこと があるか

再調整 有り $128(70.3 \%)$

無し $54(29.7 \%)$ 回答 182

4) I.I.間接の場合ホトタイマ(撮影条件増)を再調整 したことがあるか

再調整 有り $83(76.6 \%)$

$$
\text { 無し } 25(22.4 \%) \text { 回答107 }
$$

\section{2-3 調整の考察}

今回のTV，映像系の調査は，調査の期間が限られ たことや，対象個数も全国各県339施設としたことか らすべての事情を反映しているとは判定できない。し かし回答が188施設から寄せら机，おおよそその現状 を示す調査の内容と見ら扎る。

調査の対象とした回答施設の分類では，全国の大学
Table 29

回答126 施設133件 診機関 37 ，その他病院 5 である。この回答率から見て も各施設とも平均的に回答が寄せら机た内容である。

外来患者数や病床数から比較しても各施設とも TV 使用患者数は, 平均に近い数值と推察される.

TV装置の保有台数は, 大学病院が13台, 総合病院 が8台, 一段病院が 4 台, がん専門病院が 9 台, 検診 機関が車を含めて 8 台, その他病院は 3 台が平均で ある。

X線TV装置の使用範囲は，今回回答のTV装置の棇 数1624台, I.I.の総数1675本である.また装置の内容 は, 消化管用等が552台, 血管造影装置が323台, 外科 用216台, 唡診車205台, 治療位置決め用が, 116台, 泌尿器科用111台, 間接用60台, その他41台である。

I.I.の内容では，血管造影装置では12と同インチ可 変管が50.6\%，9 インチ管が33\%である，消化管用で は，9インチか $72 \% ％ 12$ と同インチ可变管が $23.5 \%$ で ある。間接，検診車では12 と同インチ可変管が97.5\% を占める.14インチ管は血管装置に総数の63\%が使用 されている。この調査では市場にでている数に比較 し，12インチ管が9イン千管より多い比率となってい るがこれは調查対象の内容によるものと見られる。

保守点検については, 購入時の検查は, 検診施設が $92 \%$ と高い。こ饥は集団娭診における精度管理の実践 の普及率が高いことが考えられる，大学病院や，がん 専門病院でも多く実施さ机ているが，一般病院や総合 病院ではまだ低い実施の状況である。この傾向は保守

Table 30

\begin{tabular}{|c|c|c|c|c|c|c|}
\hline \multicolumn{2}{|c|}{$\begin{array}{r}\text { SMPTEの使用有り } \\
\text { 無し }\end{array}$} & \multicolumn{2}{|c|}{$\begin{aligned} 37 & (20.2 \%) \\
146 & (79.8 \%)\end{aligned}$} & \multicolumn{3}{|c|}{ 回答183 } \\
\hline \multicolumn{7}{|c|}{ 2) TV系内蔵のテストパターン(SMPTE)を必要ですか } \\
\hline \multicolumn{2}{|c|}{$\begin{array}{r}\text { SMPTEの必要 } \\
\text { 不必要 }\end{array}$} & \multicolumn{2}{|c|}{$146(85.4 \%)$} & \multicolumn{2}{|c|}{ 回答171 } & \\
\hline \multicolumn{7}{|c|}{ 3）始業点検テストチャート(III用，TV用）を所有していますか } \\
\hline \multicolumn{2}{|c|}{$\begin{array}{r}\text { テストチャート有り } \\
\text { 無し }\end{array}$} & $\begin{array}{ll}87 & (48 . \\
91 & (51 .\end{array}$ & $87(48.9 \%)$ & \multicolumn{2}{|c|}{ 回答178 } & \\
\hline \multicolumn{7}{|c|}{ 4）保守点検テストチャートにて観察に必要な点検内容はなにか } \\
\hline 内 容 & コントラスト & 解像力 & 歪 & み & 拡大率 & その他 \\
\hline $\begin{array}{c}\text { 件 数 } \\
\%\end{array}$ & $\begin{array}{l}102 \\
23.9\end{array}$ & $\begin{array}{l}169 \\
39.6\end{array}$ & $\begin{array}{r}11 \\
2\end{array}$ & & $\begin{array}{l}38 \\
8.9\end{array}$ & $\begin{array}{l}2 \\
0.5\end{array}$ \\
\hline
\end{tabular}

1) TV系内蔵のテストパターン (SMPTE)を使用していますか

回答175 施設 427 件

1996 年 7 月 
点娭の実施でも同様で，保尔点娭を契䊽して定期的に 行うことにおいては，検診機関か $70 \%$ 上高いことに比 べ，大学病院等では30\%上低い内容であり，今㣪の実 施の普及が望まれる。

故障については，検䛦車の移動の関係か，検診機関 に多いが，一般病院やがん專門病院での故障は意外に 少なく，回答の分析が困難であるが，5-6年に!度の 故障と推察さ机る。この分析から平均的交換期間年数 の参考になれ代よい。またI.1.の定期交換をする施設 は，18施設 $9.8 \%$ と僅かでありそのうち㮥診機関が 67 \%を占める。これは画像の精度管理にの措置として器 期的交換が必要であることの諗識が普及してきた結果 がよく示されていると考える。今後の交換の理想年数 は，一般的には5年と見なされるが，血管聕影装置な どのI.I.については3年と推測さ北る。交換の規定につ いてはいまだ少なく，不定期な交換についても理时と しては, 画像劣化が多いが, 劣化の程度 (使朋限度)を 設定することが問題である。使用限度の設定には劣化 の程度の定期的測定が必要とされるが，既に定期的測 定結果から交換されている施設が13施設あり，その恒 常的測定法や，規定傎に眮味がある。交換の少化の程 度の目安として, 工業会では, 初期の䡛度の1/2を推 奨している。この $\mathrm{Gx}$ ，または相対粕度の測定を普及 する必要がある。交換理由の結果から見下，画像少化 のため交換，上するものが，故障による交換の理甘の 2 倍あることは，故障ゆえやむなく交換する場合よ り，積極的に画像の良化を求め推進するよい傾向を示 している.

X-TVカメラとモニターの保守管理については，娭 診機関の実施率が81\%と他の病院より高い，逆に一般 病院では50\%に充たない。一般にTV系は故障が少な く，劣化が画像に影響するまで気が付かず使用する場 合が多いと考えられる。このため装置の交換の意識も 少ない。こ机らの結果からTV系の恒常性のテストが 推奨导机る，TV系の画像不良は，経年変化による少 化が原因の場合が多くあり，TV采の画像信号レベル や，撮像管の交換，についても定期的な点蚞を受ける ベきである。TVモニターについてもI.I.同様に電源投 入使用時間が長くコントラストや輝度については，少 化の程度は激しい場合があり定期的点検交換が奖めら 机る。

TV映像系保守点枱用テストパターンについては, TV装置内蔵のSMPTEバターンを現在CT, MRI, DSA，なとCCPU内蔵の装置においてソフトを搭載して いることが多く普及しつつある.SMPTEパターンで は, TVモ二タ一系や, マルチカメラ、レザープリン タ一等の総合的な画像管理に使用されており, 今後の DR装置やX-TV装置への搭載普及が望ま扎る。

I.I.用，X-TV用のテストチャートについては，既に $50 \% の$ 施設で使用しているが特に検診機関の精度管理 では仕業点娭用として普及を奨めている。

今回の調査からI.I.やTV系の保守管理については理 解がえら机たと考えらるが，維持管理や少化の測定に
関するそのケ法や規定か望ま狆ている。こ狄らの結果 加現状の見直しを含め，映像系の日常管理を娭討寸 る必嬖がある。

\section{3. 使用者のおこなう保守管理の対応}

映像装置使用施設の管理者は, 装置の精度管理や, 多全管理に基本的責任があり，装置の管理者として次 の事を実施すべきである。

映像装置の構成は，イメージインテンシファイア 一, 光学系分配器, 撮像管, カメラコントローラ, TVモニタ，電源部などがあるが，大別としてI.I.やX 線TV装置に分けられる。 Table 31，Table 32にその試 駘項目を举げ゙る。

1)装置の新規購入に際して代様決定と引き取り娭 查(据之付け試騒)を実施する。

装置納入に当たっては，使用者立ち会いのもと 引き取り㮩査の段階で, X線映像機器の性能と 品質が新規任様と一致するかを確認する。実施 に当たってはメーカとともに行うこと。

試駘項目と厅法は, メーカの性能試騒結果 や，表示の内容に従って行うこ上，特に映像采 については，日常管理に用いるため，可能な限 り旁易に再現性のある試騒力法によって行い, そのデー夕を保守管理すること。こ机らは，そ の愹の定期点蚞時に経時変化を見るために行う ことであり，計測の力法や，内容結果につい て，具体的，定量的に記録子べきである。

映像系装置の中でも経時的劣化の著しいもの として, 1.I.の輝度低下に注意し, 輝度測定, そ の他の性能試騃並びに, 機能動作電压などを測 定する。またI.I.間接, DSA，など，X線TVを含 屯映像系について，最終出打之なる総合画像に ついて実施し，記録を残すべきである。

2) 映像系装置並びに関捙機器の定期点娭を実施す る。

定期点梚については，日常気が付かないわず かな变化や目の届かない箇所についてTV装置映 像系を含む全体で，定期点検契的をサービス会 社と契䄪し少なくとも年 2 回以上実施するのが 望ましい。映像装置の定期点検は，目視，機能 の確認を主とし，性能については装置購入引き 取り娭査の結果上の比較試騃を行うのが望まし い.

映像系では，著しい消耗劣化部品は少ないと 考えら扎るが，3-5年経過のI.I.や撮像管では， 測定蚞査の結果において交換を検討するべきで ある.またI.I.のフォ一カス電王など経時的に回 路のインーピーダンス変化で変化する可能性の あるものについては，特に電圧測定などを試騃 項目に設定すべきである。

3) 映像系装置並びに関連機器の仕業点娭を実施す 子.

仕業点枱は，装置の故障等を未然に防ぎ，円 
Table 31 映像系X線I.I.の試験項目

\begin{tabular}{|c|c|c|c|c|c|c|}
\hline & 試験項目 & 使用機器 & 適 用 & 引き取り検査 & 定期点検 & 仕業点検 \\
\hline 1) & 外観 & 目視 & & O & 0 & 0 \\
\hline 2) & $\begin{array}{l}\text { 輝度ムラ, キズ污点 } \\
\text { (グリッド縞目) }\end{array}$ & 目視 & & 0 & 0 & 0 \\
\hline 3) & 磁気的誘導変位 & $\begin{array}{l}\text { 方位 } \\
\text { 格子状チャート }\end{array}$ & & ○（初期設置方向） & & \\
\hline 4) & I.I.電源調整 & テスター & & 0 & & \\
\hline 5) & 電気的接地安全 & 抵抗測定 & JISZ4701 & 0 & & \\
\hline 6) & 入射面視野寸法 & $\begin{array}{l}\text { 同心円チャート } \\
\text { 格子状チャート }\end{array}$ & JISZ4721 & 0 & & \\
\hline 7) & 輝度分布 & $\begin{array}{l}\text { 線量率計 } \\
\text { 輝度計 }\end{array}$ & " & 0 & ○(目線) & 0 \\
\hline 8) & 変換係数 & $\begin{array}{l}\text { 線量率計 } \\
\text { 輝度計 }\end{array}$ & $"$ & 0 & 0 & 0 \\
\hline & X線遮蔽 & 線量計 & " & 0 & & \\
\hline 10) & 像ひずみ & $\begin{array}{l}\text { 試験片 } \\
\text { 格子状チャート }\end{array}$ & " & 0 & 0 & \\
\hline 11) & コントラスト比 & $\begin{array}{l}\text { 試験片 } \\
\text { 輝度計 }\end{array}$ & " & 0 & & \\
\hline 12) & $\begin{array}{l}\text { 解像度 } \\
\text { (Focus調整) }\end{array}$ & $\begin{array}{l}\text { 拡大鏡.(目視) } \\
\text { 線チャート }\end{array}$ & " & 0 & 0 & 0 \\
\hline 13) & X線中心軸の一致 & 試験片 & " & 0 & & \\
\hline 14) & 残光 & 目視 & & 0 & 0 & 0 \\
\hline 15) & 清拭 & & & & 0 & 0 \\
\hline
\end{tabular}

注）○印は各検査時に点検する項目

量子検出効率 (DQE) については参考に測定法を述べる。

入射X線自身の信号対雑音比 (SN比) とI.I.出力像のSN比のエネルギー比として測定定義されるが 今後製造側段階からIEC規格に従って普及される.

滑に日常の業務を遂行する目的で，各装置と共 に映像系について，定められたことや，書式に 従って行う。

映像系については，ウォーミングアップを兼 ねて，外観や，TVモ二タ一の映像について目 視，清掃を兼ねて行う。

映像系の始業点検には，TVテストチャートを 用いるのが望ましい。これにより映像系全体や 自動露出装置などの点検を兼ねて行う。

4）画像管理を定期的に実施する.

I.I.間接や，DSAなど，直接I.I.画像が映像とし て出力する装置が増加している。これらの装置 では入力から出力まで, 多数の機器が関与し, 画像不良が生じた場合それがどこに起因してい るかを早期に観察限定し対処しなければならな い，それにはテストチャートの撮影や，内蔵テ ストパターンなどを用いて定期的に画質評価を 実施し良好な画質を維持する。よい画質を維持 することは, 検査の重なりにより医療被曝線量 の低減に寄与する。
5）放射線技師，並びにサービスに従事するものの 資質の向上に努める。教育研修の奨め，学術的 情報の提供など，新人教育をはじめ日常の使用 装置の内容について学習し熟知する.

\section{4. 变換係数(Gx)の測定}

変換係数の測定は，詳しくはJIS-4721の6.4を参照す べきであるが，ここでは日常の管理として Gxの簡易 測定について述べる.

変換係数 $(\mathrm{Gx})$ は, 規定の条件下で, 出力像の輝度 の平均值を，入射面で測定した指定の照射線量の平均 值で除した值で示す。

$$
\mathrm{Gx}=\mathrm{L} / \mathrm{X}
$$

ここに, $\mathrm{Gx}$ : 変換係数 $\left(\mathrm{cd} \cdot \mathrm{m}^{-2} / \mu \mathrm{C} \cdot \mathrm{kg}^{-1} \cdot \mathrm{s}^{-1}\right)$

$\mathrm{L}$ : 出力像の平均輝度 $\left(\mathrm{cd} / \mathrm{m}^{2}\right)$

$\mathrm{X}$ ：入力面に拈ける入射 $\mathrm{X}$ 線の平均照射線 量率 $\left[\mu \mathrm{C} /(\mathrm{kg} \cdot \mathrm{s})\left({ }^{(1)}\right]\right.$

備考 $1 \mu \mathrm{C} /(\mathrm{kg} \cdot \mathrm{s})=\left\{1 / 2.58 \times 10^{-2} \mathrm{R} / \mathrm{s}\right\}$

ここでは，Gxの測定において工場サイドでの簏密 な測定方法と, ポケット線量計と比較的簡易なデジタ 
Table 32 X線TV系(カメラ、モニタ関連) 試鈎項目

\begin{tabular}{|c|c|c|c|c|c|}
\hline 試験項目 & 使用機器 & 適 用 & 引き取り検査 & 定期点検 & 仕業点検 \\
\hline 1）外観 & 目視 & & 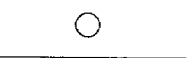 & 0 & 0 \\
\hline $\begin{array}{l}\text { 2) カメラコントローラ } \\
\text { 波形, 電圧調整 }\end{array}$ & $\begin{array}{l}\text { オシロスコープ } \\
\text { デジタルテスタ }\end{array}$ & & 0 & & \\
\hline $\begin{array}{l}\text { 2) 映像信号調整 } \\
\text { 同期, 映像（シェーテング） }\end{array}$ & オシロスコープ & & ○ & $\bigcirc$ & \\
\hline $\begin{array}{l}\text { 3）解像度 } \\
\text { FOCUS調整 }\end{array}$ & 線チャート & JISZ4916 & 0 & 0 & 0 \\
\hline $\begin{array}{l}\text { 4) モニター調整 } \\
\text { 電源 } \\
\text { 輝度 } \\
\text { コントラスト } \\
\text { 水平，垂直同期 } \\
\text { インピーダンスマッチング }\end{array}$ & 目視 & & $\bigcirc$ & $\bigcirc$ & 0 \\
\hline $\begin{array}{l}\text { 5) 総合画像 } \\
\text { ノイズ、シミ白点 } \\
\text { Uずみ, 偏移 } \\
\text { 出力画像の均一性 } \\
\text { 残像 }\end{array}$ & 目視 & & 0 & $\bigcirc$ & 0 \\
\hline $\begin{array}{l}\text { 6) 電気眍線のゆるみ } \\
\text { 付属回路の作動 }\end{array}$ & 目視 & & 0 & 0 & $O$ \\
\hline 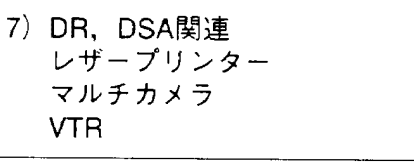 & $\begin{array}{l}\text { 尃用チャート } \\
\text { SMPTEパターン }\end{array}$ & & 0 & 0 & \\
\hline $\begin{array}{l}\text { 8) 光学係 } \\
\text { タンテムレンズ } \\
\text { 分配器 } \\
\text { アイリス調整 }\end{array}$ & テストチャート & & 0 & 0 & $\bigcirc$ \\
\hline 9）清拭 & & & 0 & $\bigcirc$ & 0 \\
\hline
\end{tabular}

注）○印は各検查時に点検する項目

ルフォトメータを使用した測定についてその測定器比 較試験を行った結果を示す.

この測定試験は1993-10-15に東芝小幡らが行った結 果である。

1) 比較測定器

線量計 Victoreen 500 プローブ550-4 アロカMYDOSE mini PDM-107

輝度計 Photoresearch Spotmeter UBD-1/4 ソニーテクトロニクス デジタルフォ トメー夕 J-17型

2) 測定条件

楾量測定 X線条件：70kv/1mA $22 \mathrm{mmAL}$, 1 分間

輝度測定 X線条件：70kv/1mA $22 \mathrm{mmAL}$ Gx測定条件 (Fig.1)

3) 測定結果

\begin{tabular}{|l|lll|}
\hline & 1 回目 & 2 回目 & 3 回目 \\
\hline Victroreen & 12 & 12 & 12 \\
Aroka & 15.6 & 15.8 & $15.7 \quad[1 \mathrm{~Sv}=100 \mathrm{R}]$ \\
\hline
\end{tabular}

輝度測定 (単位 $\mathrm{cd} / \mathrm{m}^{2}$ )

\begin{tabular}{|l|c|c|c|}
\hline & 1 回目 & 2 回目 & 3 回目 \\
\hline $\mathrm{UBD}^{\circ} 1 / 4^{\circ}$ & 59.1 & 59.2 & 59.8 \\
$\mathrm{~J}-17$ 型 & 53.5 & 53.6 & 53.9 \\
& $(91 \%)$ & $(91 \%)$ & $(92 \%)$ \\
\hline
\end{tabular}

Gx值

東芝測定系 $295\left(\mathrm{~cd} / \mathrm{m}^{2}\right) /(\mathrm{mR} / \mathrm{s})$

新測定器系 $205\left(\mathrm{~cd} / \mathrm{m}^{2}\right) /(\mathrm{mR} / \mathrm{s})$

4) 考 察

・試験結果は, 線量計, 輝度計とも再現性はあ る。ただし，経時変化は確認できていないので 今後確認する必要がある。

・絶対值については，特に線量計においては30\% の差があり，校正を実施し使用する必要があり また定期的にも校正が必要なものである。

・このような管理がなされるのであれば使用でき る可能性はある。

使用上の注意として

・線量計は線量率計ではなく積算線量計であるの で，一定時間(例：1 分間)の線量を測る。 
・䅜度計のセンサー部は吸着盤がついているの

で，I.I.上の測定位置が同じになるようにする。

この簡易測定法は，こ扎までの相対 $\mathrm{Gx}$ の簡易測定 法(RCFメータ)によるものと異なり直接デジタルホト メータJ17型を用いて出力像の平均輝度 $\left(\mathrm{cd} / \mathrm{m}^{2}\right)$ を測定 し照射線量との比率を求めることに意義がある。現在 使用中のI.I.について直接 $\mathrm{Gx}$ を簡易的に求めることが 可能である。

しかし，この簡易測定系の誤差は容認の上で使用す べきであり今後娭討を加えより良い結果がえら扎るこ とが期待される。

$\mathrm{Gx}$ の測定は，経時的に数年に及ぶことから，測定 器の管理はもちろん，測定方法についても記録が大切 であり，再現性のよい測定としなけ玌ばならない。

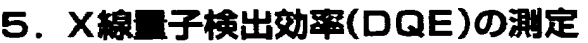

X線量子検出効率 (DQE) の測定は，IEC規格の62B116を参照すべきであるが，ここでは定義は测定法に ついて，簡単に述べる。

DQE (Ditective Quantum Efficiency：X線量子検出 効率) はX線I.I.に入射したX線量子のうち，光変換に 有効に利用される効率を表している。

1) X線I.I.のDQEは以下の要素に主に依存している.

(1) 入力空のX線透過率

(2) CsI 人力蛍光体層のX線吸収効率

(3) CsI 入力蛍光体における特性X線の発生

2) DQEの測定法には次の方法が主に用いら犯て いる.

(1)RMSノイズ測定法

(2) PHA (Pulse Hight Analysis：波高分析)法 (1)の測定法ではX線I.I.の時間応答性の影響を受 けてしまう。そこで時間応答性に影響をうけな いよう，ゼロに近い周波数で測定を行う(2)の方 法が，IECで採用され推奖さ机ている。

3) DQEは次式で定義される.

$\mathrm{DQE}=\left[(\mathrm{S} / \mathrm{N})_{\mathrm{out}}\right]^{2} /[(\mathrm{S} / \mathrm{N}) \text { in }]^{2}$

$(\mathrm{S} / \mathrm{N})$ out は出力像の $(\mathrm{S} / \mathrm{N})$ 比を, $(\mathrm{S} / \mathrm{N})$ in は入 射 $X$ 線の $(S / N)$ 比を示す.

PHA法ではX線量子によって発生する光パルス の波高分布を分析することにより(S/N) 比を求める。

（1）入力放射線の線源と線質

線源は放射線核種 ${ }^{2+1} \mathrm{Am}\left(10^{7} \mathrm{~Bq}\right)$ から放射される59.5keVのエネル ギーを有するガンマ線を用いる。

(2) (S/N) outの測定

X線I.I.より出力される光パルス を光電子增倍管により検出し，そ の出力を波形整形アンプを通して マルチチャンネルアナライザーに 導き，或る一定時間内カウントし て波高分布を求める。得られた波 高分布より次の 3 つのモーメント

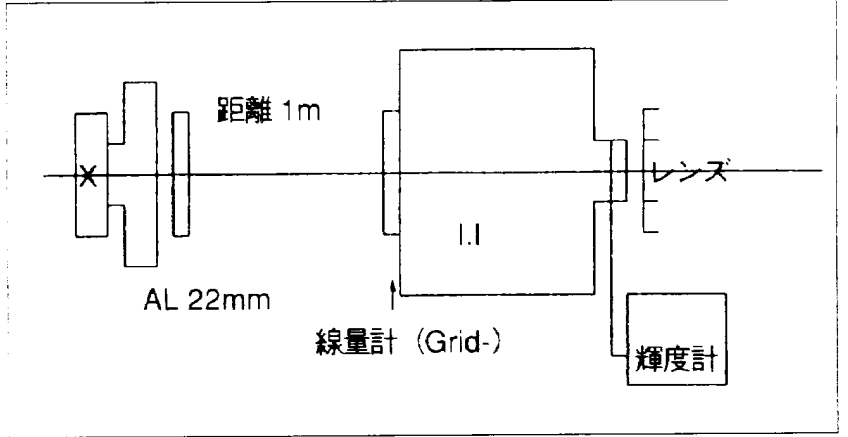

Fig. 1 Gx測定条件

を計算する。

$\mathrm{Mo}={ }_{\mathrm{i}} \Sigma \mathrm{Ni} \quad \mathrm{M}_{1}={ }_{\mathrm{i}} \Sigma \mathrm{E}_{\mathrm{i}} \mathrm{N}_{\mathrm{i}} \quad \mathrm{M}_{2}=\mathrm{i}_{\mathrm{i}} \Sigma \mathrm{E}_{\mathrm{i}}{ }^{2} \mathrm{~N}_{\mathrm{i}}$ iはマルチチャンネルアナライザーのチャン ネル番号を示し， $\mathrm{E}_{\mathrm{i}}$ はエネルギー， $\mathrm{N}_{\mathrm{i}}$ はカウ ント数. $\mathrm{M}_{1}$ 人 $\mathrm{M}_{2}$ は(S/N) outに比例した值に なる。

(3) (S/N)inの測定

同様な方法でNaIクリスタルを用いて同時間 内に入射したX線量子の全個数 $\mathrm{N}_{0}$ をカント する、、 $\mathrm{N}_{0}$ は $(\mathrm{S} / \mathrm{N})$ inに比例した值になる。

(4)DQEの決定

定義より

$\mathrm{DQE}=\mathrm{M}_{1}{ }^{2} /\left(\mathrm{N}_{0} \cdot \mathrm{M}_{2}\right)=\mathrm{AQ}_{\mathrm{Q}} \cdot \mathrm{A}_{1}$

$\mathrm{A}_{\mathrm{Q}}=\mathrm{M}_{0} / \mathrm{N}_{0}$ はX線量子の検出効率で,

$\mathrm{A}_{1}=\mathrm{M}_{1}{ }^{2} /\left(\mathrm{M}_{0} \cdot \mathrm{M}_{2}\right)$ は入力蛍光体の変換特性 を表している。

Fig.2はIEC62B116によるDQE測定方法で ある。

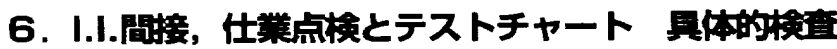
方法

1）集団健診の精度管理において仕業点検は，装置 の故障等を未然に防ぎ，円滑に日常の業務を遂 行する目的で，以下の項目について行うことに している。また毎日の撮影開始に当たり，画質 の状態を示すために、テストチャートを撮影し ておくこと。でき机ばフィルムごとにテストチ ヤートの撮影を行っておくことが望ましい(胃集 
団検診用X線装置仕業点検項目 ${ }^{9)}$ ) (Table 33).

2) I.I.保守管理に使用するテストチャートについて 以下説明する。

テストチャートは, Fig.3に示す構造となって おり，基本構成として，アクリル板内にセット された解像力チャート，アルミ階段，Pb線リン グをファントームとし，ステンレススチール板 を人体等価の吸収体とする(フィル夕)からなっ ている。(図中斜線部分)

2)-2 日常仕業点検テストチャートの使用法とし ては，通常管理撮影方法と解像力のみのテスト の場合が考えられ，その使用法を以下に示す。 通常管理撮影法では，日常の画質の状態を点 検することが主たる目的で，毎日業務開始に当 たりテスト撮影することにより画質の変動を子 エックすることになる。また解像力テストの場 合は，購入引き取り検査や，定期点検に㧍い て，撮影系のI.I.など個々にまたは総合的にチェ ックすることにある。撮影に当たっては，撮影 条件を日常の使用条件とすることにおいて，起 きた変化を捕らえることができればよい，撮影 の幾何学的条件, チャートの置かれる距離など は一定とする。Fig.4は使用撮影条件を示す。

Table 33 胃集団検診用X線装置仕業点検項目 ${ }^{9}$

\begin{tabular}{l|l}
\hline \multicolumn{1}{c|}{ 点検項目 } & \multicolumn{1}{c}{ 点検内容 } \\
\hline 1) 検診車の電源設備 & トビラ・照明・発電機・放送・コード \\
2) 高電圧発生装置 & 充放電状況の点検 \\
3) 透視撮影台 & 表示ランプ・スイッチ動作確認 \\
4) X線制御装置 & 表示ランプ・スイッチ動作確認 \\
5) X線管 & 油漏れと動作音の確認 \\
6) X線映像装置 & フィルムの存在と巻き取り動作確認 \\
I.I.・カメラ & 総合画像確認 \\
7) テストチャートの透視撮影 & 仕業点検テストチャートの実写 \\
8）補助具と防護設備 & 有無および欠損の確認 \\
\hline
\end{tabular}

3) 評価法

撮影後の仕業点検テストチャートによる画質 の管理については以下の内容についてチェック することができる。この評洒は，一連の仕業点 検として撮影にあたる装置の点検を含んでいる こと.また，撮影現像後の視覚評価，物理的評 価を行うことができる。

Fig.5にI.I.スポットカメラによるテストチャー トの映像フィルム像を示す.

画質の管理の評価法(Table 34)

每日のテストチャート撮影後評価を，一定期 間継続し，フィルムのカブリ，濃度のバラツ キ，キズ，污損，視覚解像度，コントラストに ついて比較し評価する。

この数值的結果は，濃度について見れば，自動 露出, 自動現像機, の変動率などで，安定した撮 影が行われたことを継続して管理することに意義 がある，また，同様のテストの結果は，画質の管 理について各装置別, また保有する装置間の比較 検討を行う定期的な值を得ることができる。

\section{TVモニターの管理}

最近のX線TV装置では，ほとんどの場合，モニター は一体型でシステムの一部として統合されてお り，ビデオモニタに制限を加えているため，簡 単な試験方法の適応を妨げている。このため, モニター単体の管理としては，次のような調整 に限定される。

1) モニターのみの動作を確認すること。

2)機器間の接続が完全か確かめること.

3)コントラスト, 精度の調整をすること.

しかし，最近のTVとデジタル画像をともなう システム。例えば，デジタルラジオグラフィー装 置，DSA装置，については，X線TV透視とは別に 管理について方法を考慮しなければならない。

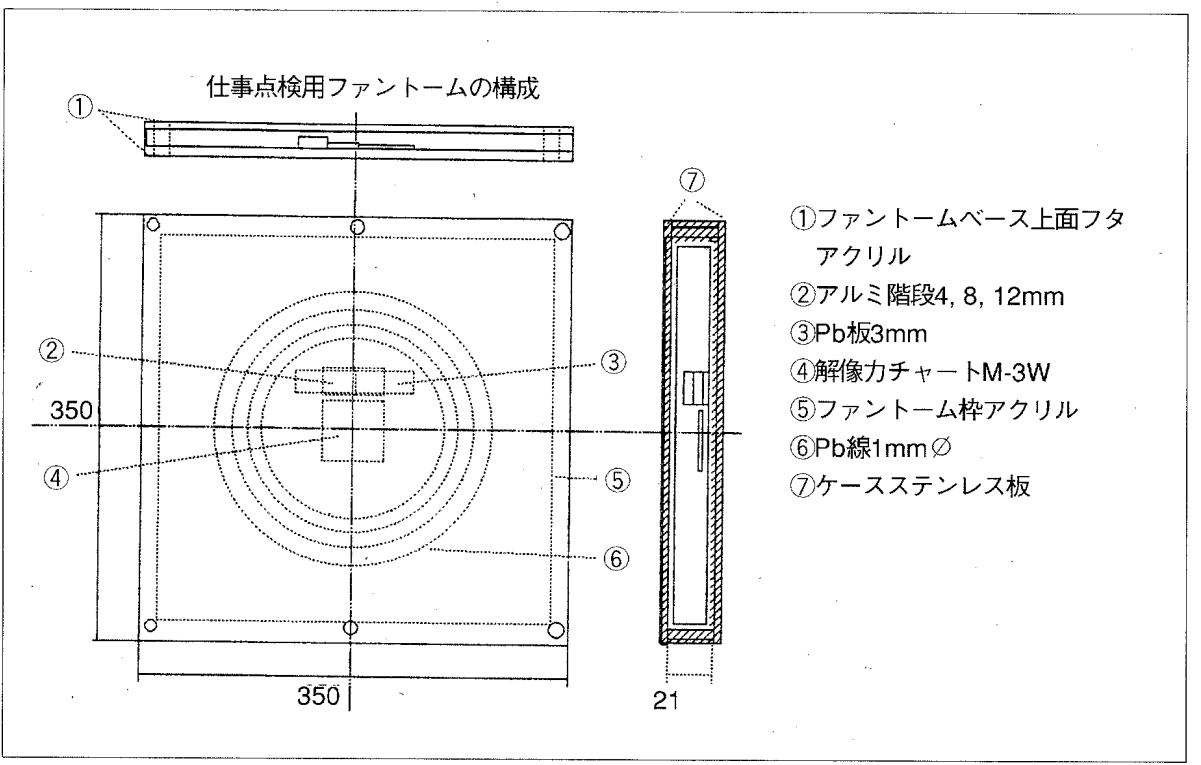

Fig. 3 組み立て図(PC-103委員会)

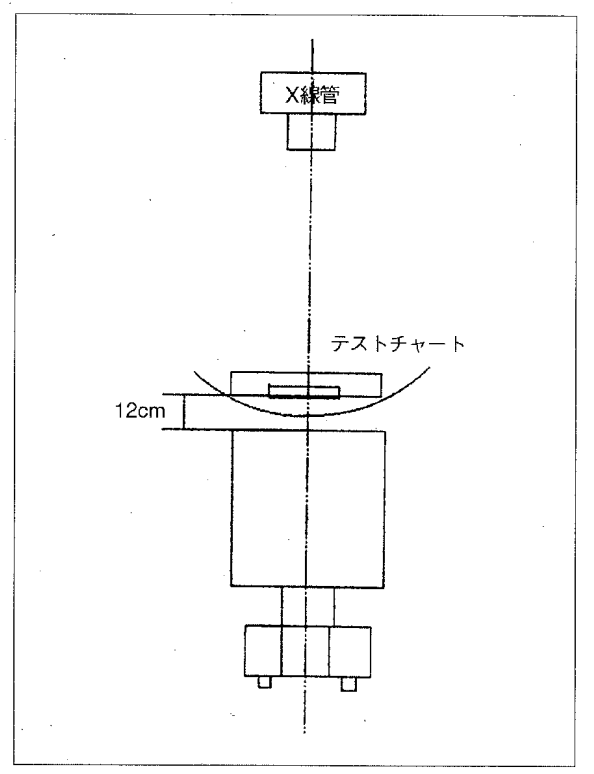

Fig. 4 日常テストチャート使用法 
[IEC 1223-2-5]医用画像部門における評価と日常試 験パート2-5：医用画像表示装置の不変性試験 (Constancy tests-Image display devices)では, これら 医用画像装置の不変性試験について，評価，調整を規 定し奨めている。主な目的は，画像診断システムに使 用される画像表示装置の性能について述へ，影響をお よぼす機能パラメータと，患者への不要照射を避ける と同時に適切な画像基準を維持するために，これらの パラメータに関する值の変動が許容内であることをチ エックする方法を定義している。この方法としては整 合性のあるテストパターンを表示して評価することに 基づいている。この目的として装置が設置されたとき 性能の基準レベルを測定する。またこの性能における 変化を判定し，調整が必要かどうかを確かめることが できる。

7-1 不変性試験の内容は, 次のようなものである.

画像表示装置を対象に，試験用画像(外部，または 内部信号)，輝度計，濃度計等を使用する。

1) 観視条件の不変性

2)グレイスケールの再現性

3 ) 画像の幾何学 (画像の歪み)

4) 空間と低コントラストの分解能

5) 画像の安定性とアーチファクト

これらの内容を不変性試験報告として記録保存する。

7-2 医用画像表示用パターンについて

画像表示不変性試験テストパターンについては, JESRA X-56医用画像表示用パターン（日本放射線機器

工業会規格)に規定するものについて述べる。

この規格は，テレビジョンモニターなどのモノクロ システムの医用画像表示装置(モニター等)拈よび八ー

Table 34 画質評価

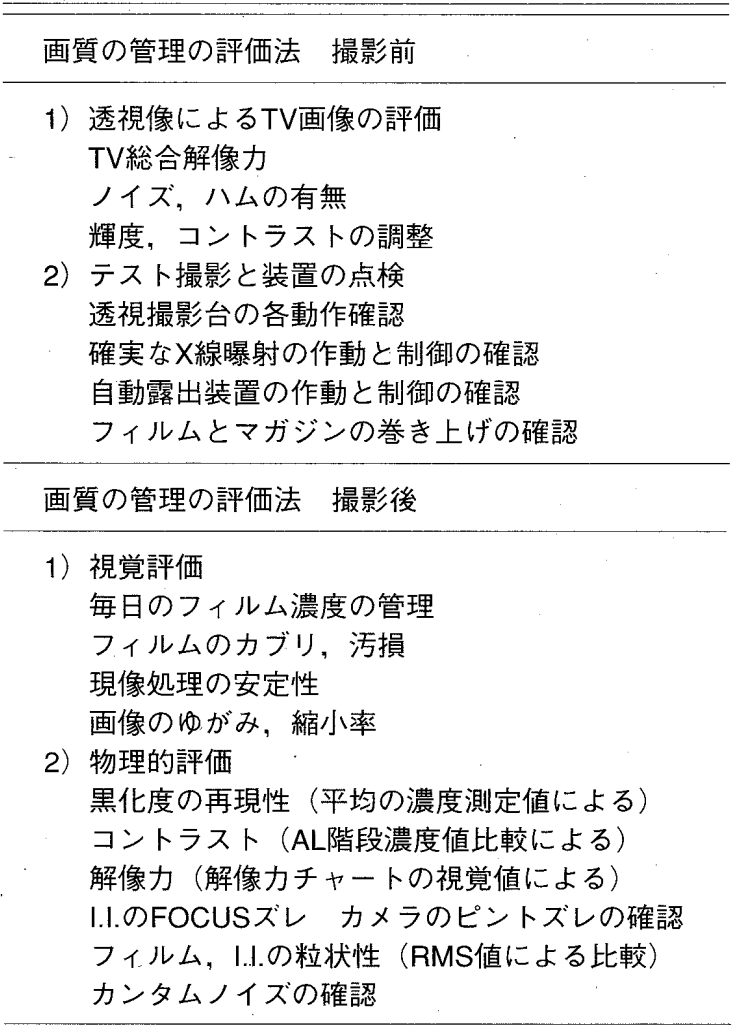

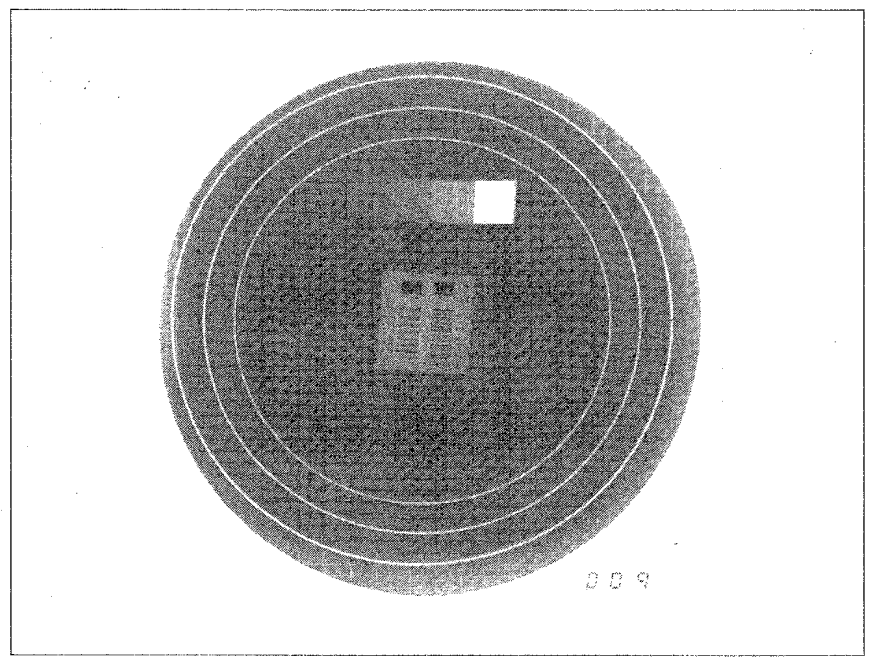

Fig. 5 仕業点検テストチャート(フィルム像)

ドコピー装置の画質を評価するために用いるテストパ ターンについて規定している。

医用画像表示用パターンを制定するに際し，国際的 整合性を考慮して，米国OSMPTE (Society of Motion Picture and Television Engineers) recommended practice RP-133に準拠している.

7-3 テストパターンについて内容を示す.

Fig.6は正方形形テストパターンを示す.

1) 背景：近似的な平均濃度(APL) $50 \%$ とする。

2)クロスハッチパターン：直線性抢よび歪み

3）高コントラストパターン：画面の解像度の比較

4) 低コントラストパターン: 解像度, 様々な画像 ノイ゙

5) グレイスケールパターン：モニターの階調再現 性

6）小コントラスト変化パターン：信号レベルの最 低，最䯩值の階調性

7) ホワイトウインドウとブラックウインドウ：

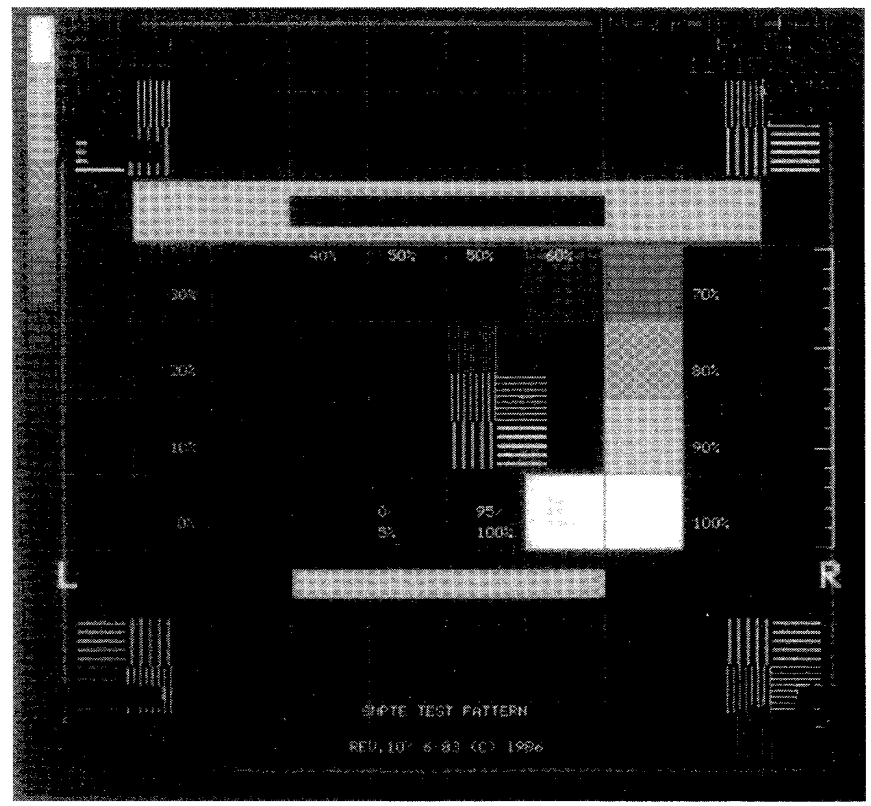

Fig. 6 SMPTE正方形テストパターン 
黑，白，レベルの安定性

8) 外周パターン: パターンの領域定義 使用に当たっては，モニターの走査線方向を考 慮して，画像を表示することが必要である。

\section{7-4 SMPTEパターンを用いた試験と内容}

ここでは，IEC1223-2-5とJESRA-X-56の内容を併せ て，実用的な試験内容を示す.

1) 観察条件の普遍性テスト：目視感

a) スクリーンの輝度

b) スクリーンに反射される輝点(外的条件

2) 画像の幾何学(画像歪み)：目視, 测定

a)クロスハッチパターン(直交パターン)

線の本数や，測定点間の長さの測定

b) 境界, 外周パターンの直線性, 歪み

3) 高, 低, コントラスト分解能：目視

a) 水平/垂直バーパターンの輝度偏差

b) 中央と四つの角のパターンの輝度偏差

c）中央部の水平バーパターンの鮮鋭度

d）四つの角の垂直バーパターンの鮮鋭度

e) 水平バーパターンの輝度偏差

f) 垂直バーパターンの輝度偏差

4) グレイスケールの再現性：目視，楎度，濃度測定

a）黑領域の輝度

b）白領域の煇度

c）グレイスケール：見分けられるステップ数，

濃度階調測定

5) 画像の安定性とアーチファクト：目視

a) 過度なフリッカー(フィールド信号)

b)不正確なインターレス

c）水平あるいは垂直の動き，摇れ

d)時間依存性のある幾何歪み

e) 蛍光体の焼き付け

f) きず污点

g) ゴースト(重なり)像

h) 黒白信号過渡期の反射像 (エンハンス度)

i)斜めに見える白線 (帰線消去信号)

これらの細目について，その現象の有無，または測 定值を判定し記録する。

\section{8. 倿 括}

今回，X線TV装置の維持管理について，実態調査を 行いその結果を元に娭討を加えた。

基本的にはTV，I.I.系など故障を未然に防ぐため定 期的な保守管理を必要とし，画像劣化やノイズ発生な どデータをチェックすることにより交換に必要な情報 を得たい。また具体的な交換時期を規定し数值的に判 断できる方法を考虑開発したい.

実態調査のアンケートの回答からも保守点検につい ては，どの施設もその必要性を認めてはいる，その結 果, 比較的以前から関心の高い娭䛦施設が精度管理の 実践の普及率が高いことが示された。しかし一般病院 や総合病院では実施は低率であることが示された。

現在TV，I.I.系においては，装置の改良と普及によ り故障が少ないことも示され，これらの保守点検に関 して一般に認識が薄れていることも指摘される。しか し装置の基本的少化は使用時間とともに進み初期の性 能を維持していることはあり得ず，恒常的測定法か確 立していることが望まれる。

調査の対象の施設中では既に定期的な測定結果をも とに系の交換を実施されているところも見られ，今後 これらの施設の測定法や規定值に興味のあるところであ るが, 工業会や，学会としても規定值の取り組みや車 検制度のような装置の使用線量を元とした使用許可判 定制度に近い一般概念ができあがることが望まれる。

保守管理の具体的方法としては，JISやJESRAの規 定に基づく各テストを具体的に示したが，これらも一 般に手軽にできることでは無い項目も見られる。しか LGx値の簡易測定法のように今後いくつかの測定器 と継続した維持管理の測定を開発普及することにより よりよい映像系の維持管理がなされると考える.

今後の動向として, TV, I.I.が基本となりDSAなど CPU内蔵の装置が普及され益々SMPTEのような, 内 蔵パターンによる管理方法が主流をなす時期が到来す ることをも考え, PACSなどの画像関連装置全体で一 貫した日常管理に取り組む必要がある。

\section{考支献}

1) IEC1223-2-5案：医用画像部門の評価とルーチンテスト パート2-5：画像表示機器一恒常性のテスト62B (CO) 106

2) IECDRAFT62B (C0) $112 \sim 117$

112：入射面視野寸法の決定

113 : 変換係数の決定

114 : 輝度分布と輝度均一度の決定

115 : 像歪みの決定

116：DQEの決定

117 : コントラスト比およびにじみ度の決定

案：MTFの決定

3) JIS-Z4721 1994医用X線イメージインテンシファイア

4) JESRA X-56医用画像表示パターン

5）日本放射線機器工業会XOP委員会X線診断装置の操作性に 関する調査研究 (遠隔操作型X楾テレビ操作性能に関するア ンケート)平成 2 年 3 月
日本放射線機器工業会XOP委員会X線診断装置の操作性に 関する調査研究(操作性の標準化)平成3年3月

6) JIS-Z47031987医用X線機械装置通則 JIS-Z4701 1988 医用X線装置通則

7）日本放射線機器工業会データブック委員会 X線診断装置 の保守管理データブック 昭和63年7月

8) 日本消化器集団検診学会関東甲信越地方会 胃集団検診の 精度管理指針 昭和 58 年 9 月

9) JESRA-X-52 胃X楾間接撮影装置通則 昭和60年3月 JESRA-X-53 胃集団唡診車システム通則 昭和62年3月

JESRA-X-53B 胃集団検診用X線装置等の点検マニュアル

10）JESRA-X-69 遠隔操作式X線テレビ装置の操作盤面 平成 5 年3月

11）JESRA-X-78 X線TV装置の製品仕様書記載様式 平成5年 3 月 12）JESRA-X-74“医用エックス線装置基準”に基づく標準試験法 